\title{
Front Matter: Volume 7500
}

, "Front Matter: Volume 7500," Proc. SPIE 7500, ICMIT 2009: Mechatronics and Information Technology, 750001 (10 February 2010); doi:

10.1117/12.861316

SPIE Event: ICMIT 2009: Mechatronics and Information Technology, 2009, Gwangju, Korea, Republic of 


\title{
PROCEEDINGS OF SPIE
}

\section{ICMIT 2009}

\section{Mechatronics and Information Technology}

\author{
Jeha Ryu \\ Kil To Chong \\ Ryojun Ikeura \\ Qingkai Han \\ Editors
}

3-5 December 2009

Gwangju (Korea, Republic of)

Organized by

Institute of Control, Robotics and Systems (Korea, Republic of)

Sponsored by

Gwangju Institute of Science and Technology (Korea, Republic of)

Applied Electromagnetics and Mechanics (Japan)

Chongqing Institute of Technology (China)

Published by

SPIE

Volume 7500 
The papers included in this volume were part of the technical conference cited on the cover and title page. Papers were selected and subject to review by the editors and conference program committee. Some conference presentations may not be available for publication. The papers published in these proceedings reflect the work and thoughts of the authors and are published herein as submitted. The publisher is not responsible for the validity of the information or for any outcomes resulting from reliance thereon.

Please use the following format to cite material from this book:

Author(s), "Title of Paper," in ICMIT 2009: Mechatronics and Information Technology, edited by Jeha Ryu, Kil To Chong, Ryojun Ikeura, Qingkai Han, Proceedings of SPIE Vol. 7500 (SPIE, Bellingham, WA, 2010) Article CID Number.

ISSN 0277-786X

ISBN 9780819478115

Published by

SPIE

P.O. Box 10, Bellingham, Washington $98227-0010$ USA

Telephone +1 3606763290 (Pacific Time) · Fax +1 3606471445

SPIE.org

Copyright (C) 2010, Society of Photo-Optical Instrumentation Engineers

Copying of material in this book for internal or personal use, or for the internal or personal use of specific clients, beyond the fair use provisions granted by the U.S. Copyright Law is authorized by SPIE subject to payment of copying fees. The Transactional Reporting Service base fee for this volume is $\$ 18.00$ per article (or portion thereof), which should be paid directly to the Copyright Clearance Center (CCC), 222 Rosewood Drive, Danvers, MA 01923. Payment may also be made electronically through CCC Online at copyright.com. Other copying for republication, resale, advertising or promotion, or any form of systematic or multiple reproduction of any material in this book is prohibited except with permission in writing from the publisher. The CCC fee code is 0277-786X/10/\$18.00.

Printed in the United States of America.

Publication of record for individual papers is online in the SPIE Digital Library.

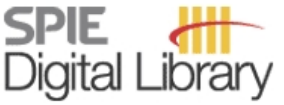

SPIEDigitalLibrary.org

Paper Numbering: Proceedings of SPIE follow an e-First publication model, with papers published first online and then in print and on CD-ROM. Papers are published as they are submitted and meet publication criteria. A unique, consistent, permanent citation identifier (CID) number is assigned to each article at the time of the first publication. Utilization of CIDs allows articles to be fully citable as soon they are published online, and connects the same identifier to all online, print, and electronic versions of the publication. SPIE uses a six-digit CID article numbering system in which:

- The first four digits correspond to the SPIE volume number.

- The last two digits indicate publication order within the volume using a Base 36 numbering system employing both numerals and letters. These two-number sets start with 00, 01, 02, 03, 04 , 05, 06, 07, 08, 09, OA, OB ... 0Z, followed by 10-1Z, 20-2Z, etc.

The CID number appears on each page of the manuscript. The complete citation is used on the first page, and an abbreviated version on subsequent pages. Numbers in the index correspond to the last two digits of the six-digit CID number. 


\section{Contents}

vii Conference Committee

ix Introduction

\section{ACTUATORS AND MECHANISMS}

750002 Analyzing kinematics of 3-TPT parallel machine tool by opening visual simulation system [7500-13]

W. Sun, Q. Han, H. Ma, B. Wen, Northeastern Univ. (China)

750003 Measuring principle and technology of accumulate pitch error of large gear [7500-35]

J. Jin, L. Dong, F. Zhao, Shenyang Univ. of Technology (China)

\section{CONDITION MONITORING AND FAULT DIAGNOSIS}

750004 Rub-impact fault vibration analysis of rotor system with the different parameters using Hilbert-Huang transform [7500-11]

Y. Yang, S. Zhang, Shenyang Agricultural Univ. (China); Q. Han, Northeastern Univ. (China);

Y. Qu, Donghua Univ. (China)

750005 Research on the water quality forecast method based on SVM [7500-23]

J. Cao, H. Hu, S. Qian, Jiaxing Univ. (China); G. Yan, Zhejiang Univ. (China)

750006 A simple peak impact force estimation method for a multi-DOF manipulator with joint servo [7500-47]

S. Jeong, Osaka Electro-Communication Univ. (Japan); T. Takahashi, Fukushima Univ. (Japan)

750007 Study about fractal neural network diagnosis method and application [7500-50]

X.-L. Hou, X.-J. Zheng, Y. Fei, Shenyang Jianzhu Univ. (China)

\section{CONTROL THEORY AND APPLICATION}

750008 CAD/CAM method application for ear shell auto-manufacturing [7500-02]

S. S. Jarng, G. Ting, Chosun Univ. (Korea, Republic of)

750009 Developmental tendency of hearing aid semi-auto-manufacturing [7500-03]

S. S. Jarng, Y. Lee, Chosun Univ. (Korea, Republic of)

\section{INFORMATION TECHNOLOGY}

7500 OA Verification duty policy for task-role-based workflow systems [7500-27]

H. Dong, Chongqing Univ. (China); Y. Liu, Chongqing Univ. of Technology (China);

Q. Huang, T. Yang, Chongqing Univ. (China); F. Ma, Univ. of International Relations (China) 
$7500 \mathrm{OB} \quad$ An improved sliding mode control method for omnidirectional mobile robots based on motion characteristics [7500-05]

C. Leng, Q. Cao, C. Lo, Shanghai Jiaotong Univ. (China)

7500 OC Intelligent process quality control system into supply chain [7500-34]

S. Wang, X. Jiang, Y. Wang, Shenyang Univ. of Technology (China)

\section{MECHATRONICS AND MEMS}

7500 OD Fluid structure interaction in electrohydraulic servovalve: a finite element approach [7500-07]

S. S. Hiremath, M. Singaperumal, Indian Institute of Technology Madras (India)

7500 OE The method design of coordinates mapping in PIV measurement system for flow field of impinging streams [7500-12]

F. Li, D. Wang, Q. Li, Shenyang Univ. of Technology (China)

7500 OF Identification and feed forward control of a flexible stacker crane [7500-49]

M. Sasaki, T. Murota, J. Usui, S. Ito, Gifu Univ. (Japan)

\section{MEDICAL AND HEALTH WELFARE INSTRUMENTS}

7500 OG Brain-computer interface design using alpha wave [7500-04]

H. Zhao, H. Wang, C. Liu, C. Li, Northeastern Univ. (China)

$7500 \mathrm{OH}$ Temporal parameter change of human postural control ability during upright swing using recursive least square method [7500-08]

A. Goto, Hirosaki Univ. (Japan); M. Ishida, Narumi Institute, Seimeikai Narumi Hospital (Japan); K. Sagawa, Hirosaki Univ. (Japan)

7500 ol Quantification of a contact stimulus by diapers [7500-20]

T. Nomata, T. Okuyama, Tohoku Univ. (Japan); H. Teraoka, Y. Murakami, K. Miyazawa, Unicharm Corp. (Japan); M. Tanaka, Tohoku Univ. (Japan)

7500 0J Palpation sensor using two PVDF films [7500-22]

T. Okuyama, M. Sone, Y. Tanahashi, M. Tanaka, Tohoku Univ. (Japan)

7500 OK Advanced haptic sensor for measuring human skin conditions [7500-29]

D. Tsuchimi, T. Okuyama, M. Tanaka, Tohoku Univ. (Japan)

$7500 \mathrm{OL}$ Characterization of a curvature sensor using a solid polymer electrolyte [7500-30] M. Otsuki, T. Okuyama, M. Tanaka, Tohoku Univ. (Japan)

7500 OM Development of a palpation sensor by using multi-signal processing: fundamental characteristics of the prototype sensor system [7500-37]

H. Nagai, T. Okuyama, M. Tanaka, Tohoku Univ. (Japan) 
$7500 \mathrm{ON}$ Some nonlinear parameters of PP intervals of pulse main peaks [7500-40]

Q. Han, Yangzhou Univ. (China); L. Wang, Liaoning Tianhua Med \& Mach Trade Corp., Ltd.

(China)

\section{ROBOTICS AND HUMAN INTERFACE}

750000 A kind of on-off control method based on EEG dimension complexity detection [7500-28] $\mathrm{H}$. Wang, State Key Lab. of Automobile Dynamic Simulation (China) and Northeastern Univ. (China); C. Li, H. Zhao, C. Liu, Northeastern Univ. (China)

7500 OP Study on optimum maneuverability in horizontal manipulation of objects with power-assist based on weight perception [7500-31]

S. M. M. Rahman, R. Ikeura, M. Nobe, H. Sawai, Mie Univ. (Japan)

$75000 Q \quad$ Technology for concrete pipe manipulator [7500-32]

B. Li, D. Wang, Shenyang Jianzhu Univ. (China); R. Lin, Shenyang Heavy Machinery \& Mining Equipment Machining Co., Ltd. (China)

7500 OR The locating ways of laying pipe manipulator [7500-33]

D. Wang, Shenyang Jianzhu Univ. (China) and Northeastern Univ. (China); B. Li, Shenyang Jianzhu Univ. (China); D. Lei, Shenyang Jianzhu Univ. (China) and Northeastern Univ. (China)

7500 OS Displacement-load force-perceived weight relationships in lifting objects with power-assist [7500-36]

S. M. M. Rahman, R. Ikeura, M. Nobe, H. Sawai, Mie Univ. (Japan)

7500 OT Mobile robot GPS/DR integrated navigation positioning technique research [7500-42] J. Wang, Shandong Univ. (China) and Chonbuk National Univ. (Korea, Republic of); Y. Zhang, Huaihai Institute of Technology (China) and Chonbuk National Univ. (Korea, Republic of); B. Li, K. T. Chong, Chonbuk National Univ. (Korea, Republic of)

$7500 \mathrm{OU}$ Safe and comfortable assistance for elderly during lie-to-sit transition [7500-43] A. Pervez, J. Ryu, Gwangju Institute of Science and Technology (Korea, Republic of)

7500 OV Quantitative research for virtual mobile robot design cycle based on PERT [7500-44] J. Wang, X. Ai, J. Zhang, Shandong Univ. (China); K. T. Chong, Chonbuk National Univ. (Korea, Republic of)

7500 OW Understanding the ideal cooperative characteristic between two humans [7500-45]

S. Abu Bakar, R. Ikeura, A. F. Salleh, T. Yano, Mie Univ. (Japan)

7500 0X Performances among various common spatial pattern methods for simultaneous MEG/EEG data [7500-46]

S. Kang, M. Ahn, S. C. Jun, Gwangju Institute of Science and Technology (Korea, Republic of)

7500 OY A motion analysis of humans performing a cooperative task in anteroposterior direction [7500-48]

A. F. Salleh, R. Ikeura, S. Abu Bakar, T. Yano, Mie Univ. (Japan) 
$75000 Z$ Distinction of two different nonstationary signals with Hilbert-Huang transform [7500-10] Q. Han, Northeastern Univ. (China); S. Zhang, Y. Yang, Shenyang Agricultural Univ. (China); Y. Qu, Donghua Univ. (China); B. Wen, Northeastern Univ. (China)

750010 A novel scheme in audio watermarking using multi-objective genetic algorithm [7500-16] A. Majid, Pakistan Institute of Engineering and Applied Sciences (Pakistan) and Gwangju Institute of Science and Technology (Korea, Republic of); T. Javed, Allama Iqbal Open Univ. (Pakistan); T.-S. Choi, Gwangju Institute of Science and Technology (Korea, Republic of)

750011 Chaotic time series analysis of vision evoked EEG [7500-18]

N. Zhang, H. Wang, Northeastern Univ. (China)

750012 Residual magnetization measurements of a motor to be used in satellites [7500-26]

A. Matsuoka, K. Matsumura, Shinshu Univ. (Japan); A. Kubota, Tamagawa Seiki Co., Ltd. (Japan); K. Tashiro, H. Wakiwaka, Shinshu Univ. (Japan)

\section{SMART MATERIALS}

750013 Performance investigation and controller design of IPMC actuator [7500-09]

L. Hao, W. Chen, Y. Zhou, Northeastern Univ. (China)

\section{UBIQUITOUS APPLICATION}

750014 Perturbation method for reliability-based sensitivity analysis [7500-21]

Y. Zhang, Northeastern Univ. (China)

750015 Study on the geometry dimension effect of heavy rail through compound roll straightening [7500-24]

P. Wang, H. Song, M. Chen, Univ. of Science and Technology Liaoning (China)

Author Index 


\title{
Conference Committee
}

\author{
Conference Chairs
}

Jeha Ryu, Gwangju Institute of Science and Technology

(Korea, Republic of)

Ryojun Ikeura, Mie University (Japan)

Qingkai Han, Northeastern University (China)

Advisory Board

Chongkug Park, Kyung Hee University (Korea, Republic of)

Boo Hee Nam, Kangwon National University (Korea, Republic of)

Ju-Jang Lee, Korea Advanced Institute of Science and Technology

(Korea, Republic of)

Young II Youm, POSTECH (Korea, Republic of)

Kil To Chong, Chonbuk National University (Korea, Republic of)

Woon Chul Ham, Chonbuk National University (Korea, Republic of)

Hiesik Kim, University of Seoul (Korea, Republic of)

GiSang Choi, University of Seoul (Korea, Republic of)

Tadashi Ishihara, Fukushima University (Japan)

Takakazu Ishimatsu, Nagasaki University (Japan)

Toshiro Higuchi, Tokyo University (Japan)

Zhongwei Jiang, Yamaguchi University (Japan)

Hikaru Inooka, Research House LOGOS (Japan)

Yixin Zhong, Beijing University of Posts and Telecommunications

(China)

Zengqi Sun, Tsinghua University (China)

Yuanzhong Lei, National Natural Science Foundation of China (China)

Bangchun Wen, Northeastern University (China)

Yimin Zhang, Northeastern University (China)

Xiaohui Shi, Chongqing Institute of Technology (China)

Yunlong Wei, Chongaing Institute of Technology (China)

Xiangwei Zhang, Guangdong University of Technology (China)

Program Committee

Hyun-Do Nam, Dankook University (Korea, Republic of)

Hyun Sik Ahn, Kookmin University (Korea, Republic of)

Wang Heon Lee, Hansei University (Korea, Republic of)

Jae Won Choi, Pusan National University (Korea, Republic of)

Yong Cheol Kim, University of Seoul (Korea, Republic of)

Sung Ki Ryu, Gyeongsang National University (Korea, Republic of)

Jungwon Yoon, Gyeongsang National University (Korea, Republic of) 
Jung Han Kim, Seoul National University of Technology

(Korea, Republic of)

Kazuhiko Takahashi, Doshisha University (Japan)

Mami Tanaka, Tohoku University (Japan)

Soichiro Suzuki, Kitami Institute of Technology (Japan)

Yoshifumi Morita, Nagoya Institute of Technology (Japan)

Kanya Tanaka, Yamaguchi University (Japan)

Koichi Sagawa, Hirosaki University (Japan)

Houtman P. Siregar, Indonesia Institute of Technology (Indonesia)

Hong Wang, Northeastern University (China)

Li Zhusu, Chongaing Institute of Technology (China)

Yi Cai, Chongqing University (China)

Qixin Cao, Shanghai Jiaotong University (China)

Dongyi Chen, University of Electronic Science and Technology of China (China)

Weijiu Huang, Chongqing Institute of Technology (China)

Shengping Liu, Chongqing Institute of Technology (China)

Yiliang Liu, Chongqing Institute of Technology (China)

Dihua Sun, Chongaing University (China)

Fuchun Sun, Tsinghua University (China)

Guoyin Wang, Chongqing University of Posts and Telecommunications (China)

Yuenan Wang, Hunan University (China)

Yaqing Tu, Logistical Engineering University (China)

Hua Zhang, Southwest University of Science and Technology (China)

Steering Committee

Gyu Sik Kim, University of Seoul (Korea, Republic of)

Il Hwan Kim, Kangwon National University (Korea, Republic of)

Taesung Yoon, Changwon National University (Korea, Republic of)

Kee Ho Yu, Chonbuk National University (Korea, Republic of)

Minoru Sasaki, Gifu University (Japan)

Takayuki Takahashi, Fukushima University (Japan)

General Secretariat

Hyusung Ahn, Gwangju Institute of Science and Technology

(Korea, Republic of)

Nyack-Yong Go, Chosun University (Korea, Republic of)

Seul Jeong, Choong-Nam National University (Korea, Republic of) 


\section{Introduction}

On behalf of the Organizing Committee of the 2009 International Conference on Mechatronics and Information Technology (ICMIT2009), we feel honored to invite you to ICMIT 2009, which will be held on 3-5 December 2009 at the Convention Center (Oryong Hall) of Gwangju Institute of Science and Technology (GIST). ICMIT has 14 years of tradition for providing opportunities for professional interactions and networking in the field of advanced mechatronics and information technology. This conference will be a forum to share ideas, information, and to enlarge human networks in mechatronics and IT under the conference theme of "Convergence of Mechatronics and IT for Better Future Life."

With the purpose of promoting a cooperative research development relationship between Asian countries, the Korea-Japan Joint Advanced Mechatronics Research Association initiated the first International Workshop on Advanced Mechatronics (IWAM) in 1995. The association changed the conference name to the International Conference on Mechatronics and Information Technology (ICMIT) in 2001, in order to keep up with the new trend of mechatronics and apply information and technology to the mechatronics technology. The ICMIT 2009 is the 8th conference in a series of the biennial conference that began in Cheju (KR) first, continuing to Nagasaki (JP), Chunchen (KR), Yamaguchi (JP), Jecheon (KR), Chongqing (CN), Gifu (JP), and now Gwangju. Now it becomes one of the leading and prestigious conferences contributing to the advancement in mechatronics technology.

We would like to express our sincere appreciation to the members of the Advisory Board, Program Committee, and Steering Committee for their valuable contributions to ICMIT 2009. Also, we thank the Gwangju Municipal, GIST, institutes, and sponsoring companies for their support of the conference.

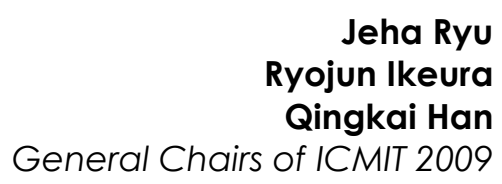


Downloaded From: https://www.spiedigitallibrary.org/conference-proceedings-of-spie on 25 Apr 2023

Terms of Use: https://www.spiedigitallibrary.org/terms-of-use 